P. Ravussin MD, M. Bayer-Berger MD, P. Monnier MD, M. Savary MD, J, Freeman MD

\title{
Percutaneous trans- tracheal ventilation for laser endoscopic pro- cedures in infants and small children with laryngeal obstruction: report of two cases
}

The case reports of two children with obstructive lesions of the larynx are presented to illustrate the advantages of iranstracheal ventilation for paediatric endoscopic laser surgery. The first patient was a four-month-old infant with inspiratory stridor due to a subglottic haemangioma obstructing 80 per cent of the lumen. The second patient was a five-year.old child with posterior synechicie of the larynx. The anaestheit and ventilation techniques were the same for both cases. A transtractiea! catheter was introduced percutaneously into the trachea under endoscopic control and connected to a high frequency jet ventilator. The advantages of this technique during laser surgery are. clear vision of the operative field, good gas exchange, elimination of ainway trauma from intubation, reduction of the hazard of airway fires, and decreased risk of aspiration of blood and debris. In addition, this method of providing oxygen andior mechanical ventilation may be extended into the postoperative period. In certain situations, this technique can be an attractive allernative to a tracheostomy with its potentially dangerous and incapacitating complications in infants and small children.

Key words

ANAESTHESIA: paediatric; EQUIPMENT: transtracheal catheter; VENTILATION: jet ventilation; LARYNX: laryngeal obstruction.

From the Departments of Anaesthesia and ENT Surgery, Faculty of Medicine, University of Lausanne, Lausanne, Switzerland.

Address correspondence to: Dr. P. Ravussin, Department of Anaesthesia, CHUV, 1011 LAUSANNE, Switzerland.
Obstructive lesions at or just below the larynx are always a difficult problem for the surgeon and the anaesthetist. Since carbon dioxide lasers were introduced in paediatric otorhino-laryngology, ${ }^{1-3}$ some obstructive lesions (e.g., benign tumours) can be treated during endoscopy. The effectiveness and safety of these procedures are related to the degree of endoscopic exposure. ${ }^{2}$ The very narrow glottic and subglottic spaces in infants and small children constitute a major problem. ${ }^{4}$ Very few anaesthetic techniques assure a completely free laryngeal endoscopic operative field.

A practical altemative to tracheal intubation and to elective tracheostomy, with its potentially dangerous and incapacitating complications in infants and small children, ${ }^{5}$ is transtracheal jet ventilation at either normal ${ }^{6}$ or high frequency. ${ }^{7}$ The first trials of transtracheal oxygenation were attempted in the early nineteen-fifties. ${ }^{8}$ In 1967 , Sanders ${ }^{6}$ was the first to report the use of a jet device to ventilate patients during bronchoscopy. Spoerel et al. ${ }^{9}$ combined jet ventilation and transtracheal ventilation, and extended the indications of transtracheal ventilation to patients undergoing surgery other than ENT surgery. Klain el al. ${ }^{7}$ combined jet ventilation, high frequency and transtracheal ventilation (high frequency jet ventilation, HFJV).

The use of transtracheal ventilation in adults has been well described, ${ }^{9-11}$ but its use in infants and small children has yet to be established. We present two cases of children with laryngeal lesions to illustrate the different options available for management of the paediatric airway during laryngeal surgery.

\section{Case reports}

Case I

A four-month-old infant, weighing $5.3 \mathrm{~kg}$, presented with 


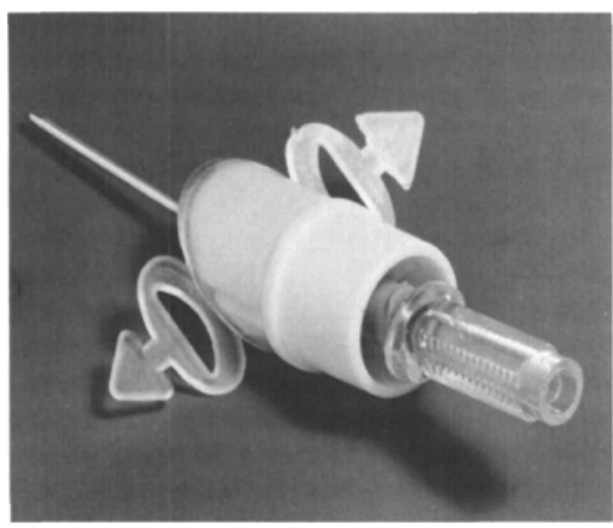

FIGURE 1 The $18 \mathrm{G}$ transtracheal catheter (paediatric size), with its stainless steel needle, double connection system, double curvature, and fixation flanges. VBM Laboratories, Medizintechnick, D-7247, Sulz/Neckar, Germany.

inspiratory stridor and brief apnoeic spells. Tracheal tug and weight loss had started three weeks before admission. Laryngoscopy performed under general anaesthesia (induction and maintenance with halothane in 100 per cent oxygen via face-mask and T-piece and intermittent succinylcholine) showed a $25 \mathrm{~mm}$ long subglottic haemangioma obstructing the tracheal lumen by approximately 80 per cent. Because of the recent development of tracheal tug, it was decided to attempt $\mathrm{CO}_{2}$-laser endoscopic resection using jet ventilation through a transtracheal catheter $^{10,11}$ (Figure 1) to ensure the best possible endoscopic exposure.

The infant was premedicated with atropine $0.04 \mathrm{mg}$ $\mathrm{kg}^{-1}$ and flunitrazepam $0.04 \mathrm{mg} \cdot \mathrm{kg}^{-1} \mathrm{PO}$. Anaesthesia was induced with thiopentone $5 \mathrm{mg} \cdot \mathrm{kg}^{-1}$ and vecuronium $0.2 \mathrm{mg} \cdot \mathrm{kg}^{-1}$. A $2.5 \mathrm{~mm}$ ID (OD $4 \mathrm{~mm}$ ) bronchoscope, was then passed into the trachea, beyond the tumour and connected to a $T$-piece breathing system, thereby assuring good oxygenation and precise endoscopic control of catheter placement. Anaesthesia was maintained with 100 per cent oxygen, alfentanil $5 \mathrm{mg} \cdot \mathrm{kg}^{-1}$ and vecuronium $0.05 \mathrm{mg} \cdot \mathrm{kg}^{-1}$, as needed.

A transtracheal catheter was introduced percutaneously between the first and second tracheal rings. Despite simultaneous tracheal and oesophageal endoscopy the catheter was seen to enter the oesophageal lumen and was immediately withdrawn. On the second attempt intratracheal placement distal to the tumour was achieved and the stylet was removed. The tip of the catheter lay $5 \mathrm{~mm}$ proximal to the carina. The cannula was then connected (Figure 2) to a high frequency jet ventilator (Akutronic MK 800 MS, Cardio Medical, Arth, Switzerland). The

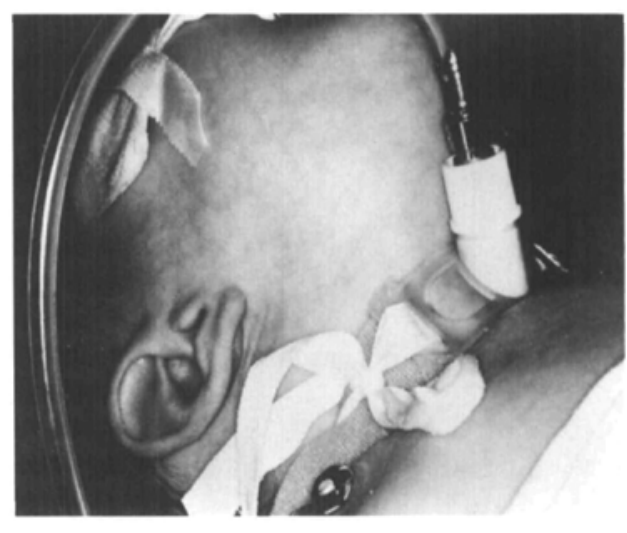

FIGURE 2 Extemal view of the catheter in place (Case I) connected to the non-compliant tubing of the HFJV system.

settings were: minute volume $500 \mathrm{ml} \cdot \mathrm{kg}^{-1}$, driving pressure $30 \mathrm{kPa}$ (4.35 PSI), inspiratory: expiratory ratio 1:2 and a frequency of $150 \mathrm{~min}^{-1}$. This ventilator is used with a high-flow gas blender connected to the gas inlet fitting with high-pressure tubing. Oxygen 100 per cent was administered until the tenth minute of HFJV, and thereafter 50 per cent in $\mathrm{N}_{2} \mathrm{O}$. Peroperative ventilation was assessed by means of a precordial stethoscope and arterial blood gas analysis (Table).

The obstruction was relieved with a 4 mmID (OD $7.8 \mathrm{~mm}$ ) paediatric bronchoscope adapted for use with a $\mathrm{CO}_{2}$-laser. The tumour was partially removed and the tracheal lumen was increased to approximately 90 per cent of normal. The procedure lasted two hours 30 minutes. At the end of the procedure, the vecuronium was antagonized with neostigmine $0.06 \mathrm{mg} \cdot \mathrm{kg}^{-1}$ and atropine $0.03 \mathrm{mg} \cdot \mathrm{kg}^{-1}$. Once the patient was awake, the transtracheal catheter was disconnected from the ventilator but left in place, and was well tolerated for 12 hours. The postoperative course was uneventful. The diagnosis of haemangioma was confirmed by histology.

Endoscopic examination performed eight weeks later showed a local recurrence. The tracheal lumen was sufficiently large at this time to permit jet ventilation

TABLE Intraoperative arterial blood gas results. $\left(\mathrm{FtO}_{2}=0.5\right)$

\begin{tabular}{lll}
\hline & Casel & Casell \\
\hline $\mathrm{PaO}_{2}(\mathrm{mmHg})$ & 73.5 & 110 \\
$\mathrm{SaO}_{2}(\%)$ & 96.1 & 99 \\
$\mathrm{PaCO}_{2}(\mathrm{mmHg})$ & 34 & 43 \\
$\mathrm{HCO}_{3}\left(\mathrm{mmol} \cdot \mathrm{L}^{-1}\right)$ & 22.8 & 23 \\
$\mathrm{pH}$ & 7.45 & 7.38 \\
\hline
\end{tabular}


through the bronchoscope used for laser resection with unobstructed escape of insufflated gases $\left(\mathrm{N}_{2} \mathrm{O} / \mathrm{O}_{2}: 2 / 1\right)$. A second endoscopic examination nine weeks later showed no local recurrence.

\section{Case II}

A five-year-old girl presented with progressive dyspnoea and moderate inspiratory and expiratory stridor due to a glottic and subglottic posterior synechiae following tracheal intubation of four days duration, five months previously. It was decided to attempt to free the vocal cords by endoscopic $\mathrm{CO}_{2}$-laser resection, using the technique of transtracheal ventilation. After denitrogenation with 100 per cent oxygen, general anaesthesia was induced with thiopentone $4 \mathrm{mg} \cdot \mathrm{kg}^{-1}$ and fentanyl 2 $\mu \mathrm{g} \cdot \mathrm{kg}^{-1}$ and muscle relaxation was achieved with vecuronium $0.1 \mathrm{mg} \cdot \mathrm{kg}^{-1}$. A paediatric transtracheal catheter was introduced with ease through the cricothyroid membrane, under endoscopic control. The catheter was connected to the high frequency jet ventilator; the escape of insufflated gases was unobstructed. The ventilator was set to deliver a minute volume of $350 \mathrm{ml} \cdot \mathrm{kg}^{-1}$ at a driving pressure of $50 \mathrm{kPa}$ (7.25 PSI) and an inspiratory to expiratory ratio $1: 2$, at a frequency of $100 \cdot \mathrm{min}^{-1}$. The result of an intraoperative arterial blood gas analysis is presented in the Table. The child awoke rapidly and calmly after the procedure.

\section{Discussion}

Recent advances in therapeutic endoscopy, ${ }^{12,13}$ together with refinements of the accompanying techniques of anaesthesia, have made possible inspection and surgical procedures on the larynx and the use of microsurgical techniques without the presence of an endotracheal tube. For infants and small children, the wide range of instruments available (paediatric micro-laryngoscopes for suspension procedures and branchoscopes coupled to $\mathrm{CO}_{2}$-laser) and the use of special anaesthetic systems (jet ventilation through transtracheal catheters) will assure optimal conditions for the surgeon and will avoid tracheostomy or tracheal intubation. ${ }^{14}$ The transtracheal catheter we used is the paediatric equivalent of one previously described, ${ }^{10.11} 18 \mathrm{~g}$, ID $0.8 \mathrm{~mm}$, length $37 \mathrm{~mm}$, which can be attached to a conventional breathing system via its $15 \mathrm{~mm}$ diameter connector, or to a high pressure source, e.g., a HFJV system ${ }^{\top}$ or a jet device operating at frequencies of $15-30 / \mathrm{min}^{6,9}$ via its luer lock connector (Figure 1). It can be left in place after the procedure, should glottic or subglottic aedema develop.

A small endotracheal tube would have passed the lesion in the two cases presented. Nevertheless, such a tube might also have traumatized the lesion ${ }^{14}$ and would have impeded vision of the operative field. ${ }^{14,15}$ In the first case, it would have hindered the bronchoscope from passing the tumour for lateral resection, and, in the second case, would have made resection of the posterior synechiae of the vocal cords impossible. Intubation might also cause spread of neoplastic cells and tissue. ${ }^{15}$

A nasotracheal catheter with jet ventilation would have presented the same disadvantages. Furthermore placement of a catheter through the vocal cords could obstruct exhalation to a significant degree. ${ }^{15}$

An anaesthetic technique using intravenous agents (ketamine, benzodiazepines, barbiturates, narcotics) and spontaneous ventilation or intermittent paralysis does not offer the security of adequate gas exchange during this type of surgery in infants and small children. Jet ventilation through a micro-laryngoscope ${ }^{16}$ might have been used for the second case but not for the first one. However, we judged that jet ventilation delivered proximal to such a severe stenosis would have been inadequate, and that vibrations of the vocal cord-false cord region produced by the jet ventilation would have interfered with the surgical procedure.

The advantages and complications of percutaneous transtracheal jet ventilation have been described ${ }^{9-11,14,17-19}$ during both anaesthesia and emergency airway management. In infants and small children, although transtracheal ventilation is obviously more difficult even in expert hands, ${ }^{18}$ the technical problems are outweighed by the advantages of avoiding intubation when the diameters of the glottic and subglottic area are critically small. ${ }^{4}$ The subglottic diameter is less than $4.5 \mathrm{~mm}$ in nconates, and oedema of $1 \mathrm{~mm}$ thickncss will diminish the lumen by about 30 per cent ${ }^{20}$ Trauma to the mucosa due to intubation may lead to postoperative oedema, which could require either reintubation or tracheostomy. These are best avoided, since intubation would compromise the advantages of laser treatment (minimal tissue trauma, wound healing without retraction) and tracheostomy would incur the risks of bleeding and late tracheal stenosis, especially in very small children.

We conclude that transtracheal ventilation, either at a normal rate or at high frequency, is a safe and useful technique for certain paediatric endotracheal and endolaryngeal procedures. The insertion of the transtracheal catheter should be performed by an experienced practitioner, under endoscopic control. An adequate exit route for the insufflated gas mixture must be ensured. If a high frequency jet ventilator is used, it should be equipped with an alarm and fail-safe system which interupts the jet inflow automatically when intratracheal pressure rises above a present level. Since pneumothorax and pneumo-rnediastinum may become rapidly life-threatening, especially in paediatric patients, a high level of vigilance must be maintained. We have previously recommended this tech- 
nique for use in adults in whom the best possible endoscopic exposure is required and/or in whom endotracheal intubation is difficult because of partially obstructive lesions of the mouth, larynx and upper trachea. ${ }^{10} \mathrm{We}$ now extend the indications to include infants and small children in whom this technique offers, for certain ENT procedures, major advantages because of the small dimensions of the respiratory tract at this age.

\section{Acknowledgements}

We express our gratitude to Dr. David Archer for his review and assistance in writing the manuscript and to $F$. Gagneaux and $C$. Grosjean for their secretarial assistance.

\section{References}

1 Healy $G B, M c G i l l T$. Strong MS. Surgical advances in the treatment of lesions of the pediatric airway. The role of the $\mathrm{CO}_{2}$-laser. Pediatr 1978; 61: 380-3.

2 Healy $G B, M C G i l l T$, Simpson GT, Strong MS. The use of the carbon dioxide laser in the pediatric airway. J Pediatr Surg 1979; 14: $735-40$.

3 Mizono G. Dedo $H H$. Subglottic hemangiomas in infants: treatment with $\mathrm{CO}_{2}$-laser. Laryngascope 1984; 94: 638-41.

4 Fearon $B$, Whaten JS. Tracheal dimensions in the living infant. Ann Otol Rhinol Laryngol 1967; 76: 964-74.

5 Greene DA. Tracheostomy or not? JAMA 1975; 234: $1150-1$.

6 Sanders $R D$. Two ventilating attachments for bronchoscopes. Del Med J 1967; 39: 170-5.

7 Klain $M$. Smith $B R$. High frequency percutaneous transtracheal jet ventilation. Crit Care Med 1977; 5: 280-7.

8 Jacoby JJ, Hameiberg W, Recd JP, Gillespie B, Hitchcock FA. Simple method of artificial tespiration. Am I Physiol 1951; 167: 798-9.

9 Spoerel WE, Narayanan PS, Singh NP. Transtracheal ventilation. Br J Anaesth 1971; 43: 932-9.

10 Ravussin $P$, Freeman J. A new transtracheal catheter for ventilation and resuscitation. Can Anaesth Soc J 1985; 32 : $60-4$.

11 Tunstall ME, Sheikh A. Failed intutation protocol: oxygenation without aspiration. Clinics in Anaesthesiology 1986; 4 : 181-4.

12 Strongs MS, Vaughan CW, Polanyi Tet al. Bronchoscopic carbon dioxide laser surgery. Ann Otol Rhinol Laryngol 1974; 83: 769-76

13 Healy GB, McGill T, Friedmann EM. Carbon dioxide laser in subglottic hemangioma, an update. Ann Otol Rhinol Laryngol 1984; 93: 330-3.

14 Basset $J M$, Eurin B, François $M$, Hertzog C, Laquerriere $M C$. Ardoin $C$. La ventilation à haule fréquence par voie intercricothyroïdienne dans les endoscopies ORL. Notre expérience de 83 cas. Ann Otol Rhinol 1982; 99: 159-66.
15 Carden $E$, Ferguson GB. A new technique for microlaryngeal surgery in infants. Laryngoscope 1973; 83:691-9.

16 Urban G. Laryngeal microsurgery without intubation. South Med J 1976; 69: 828-30.

17 Wagner DJ, Coombs DW, Doyle SC. Percutaneous transtracheal ventilation for emergency dental appliance removal. Anesthesiology 1985; 62: 664-6.

18 SpoerelWE, Singh NP, Sawhney KL. Transtracheale Beatmung für endolaryngeale Eingriffe. Der Anaesthetist 1971; 21: 59-62.

19 Patel $K F$, Hicks $J N$. Prevention of fire hazards associated with use of carbon dioxide lasers. Anesth Analg 1981; 60: $885-8$.

20 Hollinger $P M$, Kutnick SL, Schilo JA, Hollinger LD. Subglottic stenosis in infants and children. Ann Otol Rhinol Laryngol 1976; 85: 591-9.

\section{Résumé}

Afin d'illustrer les avantages de ta ventilation transtrachéale ches l'enfant se présentant pour chirurgie endoscopique gloftique er sousglottique au laser- $\mathrm{CO}_{2}$, nous présennons detur cas. Le premier cas est celui d' un mourisson de quatre mois présentant un stridor inspiratoire sur hémangiome sousglottique obstruant à 80 pour cent la lumière trachéale. Le deuxième cas est un enfant de cing ans présentant un stridor inspiratoire sur synéchies glottiques postérieures et sousglottiques. Les techniques d'anesthesie et de ventilation ont áté tes mêrmes dans les deux cas. Un cathéter transtrachéal a été intséré sous rontrôle endoscopique et relié à un ventilateur à haute fréquence. Les avantages de la ventilation transtrachéale pour la chirurgie au laser sont: une vision parfaite du champ opératoire, des échanges gazeux satisfaisants, l'elimination du trakmatisme muqueux dû à l'intubation, une suppression des risques d' ignition du tube endotrachéal, une diminution du risque d' aspira. tion de sang ou de débris. De plus, la possibilité d'apport d'oxygène en phase post-opératoire est offerre en laissamt le cathéter en place. Dans certaines situations, cette technique est une alternative séduisante permet tant d' éviter une trachéotomie et son cortège de complications potentiellement dangereuses chez le nourisson et le petit enfant. 